\title{
Efektivitas Pembelajaran Matematika Menggunakan Media Pemberian Tugas Google Form Di Masa Pandemi Covid-19 Terhadap Hasil Belajar Siswa
}

\author{
Wiwin Indah Lestari' ${ }^{1)}$, Eric Dwi Putra ${ }^{2)}$ \\ ${ }^{1)}$ SMPN 1 Tajinan Malang \\ ${ }^{2)}$ IKIP PGRI Jember \\ Email: windy3zata88@gmail.com,dwieric454@gmail.com
}

\begin{abstract}
This study aims to describe the effectiveness of learning mathematics using google form assignment media during the Covid-19 pandemic on student learning outcomes. This research is a descriptive study with a qualitative approach. Methods of data collection using tests and questionnaires. The subjects in this study were students of class VII at SMPN 1 T Kerajinan Malang with a total of 252 students. The results showed that student learning outcomes that completed reached $75.4 \%$ and were in good classification; Student responses to Google Form assignments are in a good category. So that from the two categories it can be concluded that learning mathematics using the Google Form assignment media during the Covid-19 pandemic is said to be effective.
\end{abstract}

Keywords: Google Form, Learning Outcomes, The Covid-19 Pandemic.

\begin{abstract}
ABSTRAK
Penelitian ini bertujuan untuk memaparkan efektivitas pembelajaran matematika menggunakan media pemberian tugas Google Form di masa pandemi Covid-19 terhadap hasil belajar siswa. Penelitian ini merupakan penelitian deskriptif dengan pendekatan kualitatif. Metode pengumpulan data menggunakan tes dan angket. Subyek pada penelitian ini adalah siswa kelas VII di SMPN 1 Tajinan Malang dengan jumlah 252 siswa. Hasil penelitian menunjukkan hasil belajar siswa yang tuntas mencapai $75.4 \%$ dan berada pada klasifikasi baik; respon siswa terhadap pemberian tugas Google Form berada pada kategori baik. Sehinga dari kedua kategori bisa diambil kesimpulan bahwa pembelajaran matematika dengan menggunakan media pemberian tugas Google Form dimasa pandemi Covid-19 dikatakan efektif.
\end{abstract}

Kata Kunci: Google Form, Hasil Belajar, Pandemi Covid-19. 


\section{PENDAHULUAN}

Pembelajaran adalah interaksi antara guru dengan siswa, dimana terjadi proses komunikasi secara intens serta terarah dengan tujuan mencapai indicator pembelajar yang telah ditetapkan. Pelaksanaan pembelajaran yang baik sangat memerlukan adanya interaksi oleh seluruh komponen yang terlibat didalam proses pembelajaran baik antara siswa bersama guru ataupun antar siswa . selama pandemi Covid-19 terjadi, pembelajaran tetap dituntut supaya dapat terlaksana dengan baik. Banyak kendala yang dialami siswa selama proses belajar, karena mereka merasa belajar itu harus tatap muka, padahal belajar bisa dilaksanakan dimanapun saja, kapanpun saja, serta dengan bentuk media apa saja.

Anthony Robbins (Trianto, 2011) menberikan definisi belajar merupakan proses menciptakan hubungan antara pengetahuan yang telah dipahami siswa serta pengetahuan baru yang diperoleh siswa. Dari definisi tersebut dimensi belajar terdapat beberapa unsur, diantaranya: (a) menciptakan hubungan, (b) suatu pengetahuan siswa yang telah dipahami, serta (c) suatu (pengetahuan) yang sifatnya baru. Maka didalam makna belajar, tidak hanya berasal dari suatu yang belum dikuasai (nol), akan tetapi adalah keterkaitan antara dua pengetahuan yang telah ada atau telah dimiliki siswa dengan pengetahuan yang baru.

Pelajaran matematika dikenal dengan pelajaran bersifat abstrak, sehingga dalam proses pembelajaran dibutuhkan strategi yang sesuai diwaktu mengajarkan matematika supaya siswa bisa dengan mudah memahami suatu konsep dalam materi. Didalam proses pembelajaran sampai sekarang ini sebagian besar siswa mengalami kesulitan disaat belajar matematika. Ini dikarenakan banyaknya faktor-faktor tertentu, salah satunya yaitu anggapan siswa bahwa pembelajaran matematika sulit untuk menghafal rumus-rumus. Hal ini sesuai pendapat Putra \& Amalia (2019) yang menyatakan bahwa saat proses pembelajaran matematika berlangsung sering ditemukan siswa hanya menghafal rumus, hal ini terlihat waktu siswa mengerjakan maupun saat menyelesaikan soal menggunakan rumus banyak siswa yang meghadapi problem serta kesulitan. Ada juga yang merasa dengan adanya pandemi seperti sekarang ini mereka jadi kurang efektif dalam menerima pembelajaran secara daring sehingga menyebabkan hasil belajar nya menurun. Semua hal ini tidak hanya sematamata karena kesalahan siswa tapi bisa juga disebabkan oleh penggunaan media 
pembelajaran yang tidak tepat. Dalam perkembangan zaman saat ini, dunia pendidikan akan menyongsong perubahan yang dipengaruhi oleh berkembangnya IPTEK.

Dengan era Teknologi disaat masa-masa sekarang ini mengharuskan didalam pendidikan harus dapat menyesuaikan bersama berkembangnya teknologi yang sangat pesat serta canggih sehingga diantara tujuannya yaitu memberikan kemudahan dalam pelaksanaan pendidikan. Disaat era teknologi saat ini, terdapat media yang menggeser pembelajaran yang biasanya dilakukan tatap muka di kelas secara langsung antara siswa bersama guru menjadi tanpa adanya tatap muka langsung. Salah satu bentuk cara yang dapat guru gunakan didalam proses belajar mengajar pada masa pandemi seperti sekarang ini adalah menggunakan media pemberian tugas yang berupa google form.

Di dalam dunia akademisi, penggunaan Google Form bisa dilakukan untuk memberikan kuis, survei terhadap efektivitas proses pembelajaran, mengumpulkan hasil jawaban pertanyaan terbuka dan lain-lain (Mansor, A. Z, dalam Sianipar, A.Z. 2019). Google Form merupakan fitur gratis dari email Google. Penggunaan Google Form selain untuk survey dan sejenisnya juga dapat dimanfaatkan sebagai ujian online. Pada Google Form kita bisa membuat berbagai mode soal dari pilihan ganda, jawaban singkat, maupun jawaban dengan penjelasan. Selain itu kita juga dapat membuat soal yang menggunakan gambar atau yang lainnya. Karena kelebihannya inilah pemberian tugas dengan menggunakan media Google Form dirasa sangat efektif dan bisa meningkatkan hasil belajar siswa dalam masa pandemi Covid-19 ini.

Menurut Sianipar, A.Z. (2019), Google Form di dalam dunia pendidikan mempunyai banyak fungsi, diantaranya: a) Memberikan tugas latihan/ulangan secara online menggunakan laman website, b) Mengumpulkan pendapat pada laman website, c) Mengumpulkan bermacam data dosen/mahasiswa/guru/siswa pada halaman website, d) Menciptakant formulir pendaftaran berbasis online pada sekolah, e) Memberikan kuesioner terhadap orang-orang. Pada aplikasi berbasis we tersebut ,siswa bisa mengumpulkan tanggapan serta jawaban ulangan/kuis maupun kuesioner dengan sangat cepat dimanapun siswa berada karena bisa memakai aplikasi internet pada komputer / laptop seta lewat handphone.

Dengan media pemberian tugas Google Form seperti ini, siswa bisa mengutarakan pertanyaan walaupun tidak dilakukan secara langsung/ tidak perlu tatap muka dengan guru, mengutarakan pendapat, mempunyai jiwa kepemimpinan dan 
membuat siswa tetap melaksanakan kegiatan belajar dari rumah, sehingga jika terdapat siswa yang tidak memahami materi yang diberikan oleh guru akan menjadi lebih paham sebab adanya pemberian latihan secara rutin. Penggunaan media pemberian tugas seperti ini diharap siswa merasa senang serta antusias saat didalam pembelajaran sehingga bisa menyelesaikan masalah. Selain itu juga diharapkan bisa menambah suasana baru untuk pembelajaran matematika. Sehingga diharapkan dalam pelaksanaan pembelajarannya, untuk keterampilan proses yang ada bisa berdampak positif kepada hasil belajar.

Surya (2004) menjelaskan bahwa keefektifan dari program pembelajaran dapat ditandai dengan beberapa ciri-ciri diantaranya: 1) Berhasil mengantarkan siswa memperoleh tujuan-tujuan instruksional yang sudah ditetapkan, 2) Menyajikan pengalaman belajar secara atraktif, siswa dilibatkan secara aktif sehingga akan menunjang tercapainya tujuan instruksional, 3) mempunyai sarana-sarana penunjang pada proses belajar mengajar.

Keterkaitan dengan hasil belajar siswa merupakan kemampuan yang didapat siswa setelah proses belajar sehingga bisa memberikan suatu perubahan tingkah laku baik itu pemahaman, sikap, pengetahuan serta keterampilan pserta sedemikian hingga siawa menjadi lebih baik dari sebelum siswa mengikuti proses pembelajaran. Hasil belajar adalah hal penting dalam menentukan indikator proses belajar. Untuk mengukur tercapai atau tidak dari indikator proses pembelajaran yaitu salah satunya dengan melihat hasil belajar.

Hasil belajar merupakan salah satu tingkat penguasaan yang akan dicapai oleh siswa saat melaksanakan proses belajar mengajar dan cocok dengan tujuan yang ditetapkan. Dimyati dan Mudjiono (2015) menjelaskan maksud hasil belajar yaitu proses melihat sejauh mana pembelajaran yang telah dikuasai siswa saat sudah melaksanakan kegiatan belajar mengajar, ataupun keberhasilan apa saja dari siswa yang telah dicapai setelah melaksanakan kegiatan proses pembelajaran dan ditandai dalam bentuk huruf, angka maupun simbol tertentu sesuai hasil kesepakatan dari pihak penyelenggara. Dari berbagai teori tersebut tentang hasil belajar, maka dapat disimpulkan bahwa hasil belajar pada penelitian adalah hasil belajar (perubahan tingkah laku: afektif, kognitif serta psikomotorik) setelah siswa mengikuti proses 
pembelajaran dengan media pemeberian tugas Google Form ternyata bisa meningkatkan hasil belajar yang ditunjukkan dengan hasil evaluasi berupa nilai.

Beberapa hasil penelitian terdahulu menunjukkan penggunaan Google Form sangat baik diterapkan di dalam pembelajaran dan dunia pendidikan. Misalnya yaitu Sianipar, A.Z. (2019), didalam hasil penelitian menunjukkan Google Form bisa menjadi salah satu software yang direkomendasikan dalam pembuatan alat penilaian dengan cara online. Selanjutnya didalam penelitiannya juga menjelaskan bahwa respon mahasiswa terhadap Google Form menunjukkan respon yang baik jika menjadi alternatif penilaian kepuasan pelayanan mahasiswa. Di dalam penelitiannya Santoso (2019), juga menjelaskan bahwa media penilaian dengan Google Form efektif dalam meningkatkan hasil belajar siswa kelas IX SMPN 9 Purworejo.

Dari permasalahan diatas, maka peneliti sangat merasa perlu melaksanakan penelitian tentang efektifitas pemberian tugas Google Form. Dalam penitian ini, diharapkan dapat mempermudah guru dalam mengajar secara online. Penelitian ini bertujuan menggambarkan efektivitas pembelajaran matematika memanfaatkan media pemberian tugas Google Form di masa pandemi Covid-19 terhadap hasil belajar siswa.

\section{METODE PENELITIAN}

Penelitian dilasanakan menggunakan deskriptif dengan pendekatan kualitatif. Jenis penelitian tersebut dipilih karena peneliti akan mengkaji kondisi alami siswa saat pemberian tugas google form, serta proses pembelajaran khususnya yang terkait dengan fokus penelitian. Penelitian dilaksanakan di Kabupaten Malang, Kecamatan Tajinan. Pengambilan data dilakukan di SMPN 1 Tajinan. Subjek penelitian yaitu siswa kelas VII di SMPN 1 Tajinan Malang sebanyak 252 siswa. Pengambilan sampel dilakukan dengan menggunakan stratified sampling (teknik sampling bertingkat). Sedangkan langkah-langkah penelitian dibedakan dalam empat bagian diantaranya: tahapan persiapan, pelaksanaan, analisis data serta penulisan laporan.

Penelitian ini menggunakan intrumen-instrumen diantaranya: RPP, Lembar Kerja siswa, Tes Hasil belajar, angket respon. Objek yang diteliti yaitu jawaban tes hasil pengerjaan oleh 252 siswa, soal matematika yang dibuat dan dikemas berupa bentuk pilihan ganda sebanyak 30 soal. 
Berdasarkan penjelasan diatas, bahwa data hasil penelitian yang telah didapat peneliti selanjutnya dilakukan analisis dengan cara berikut:

1. Analisis Hasil Belajar Siswa

Hal yang dilakukan analisis dari jawaban tes yaitu hasil belajar matematika siswa yang dikelompokkan menjadi sangat baik, baik, cukup, kurang serta sangat kurang dalam menyelesaikan soal-soal pemecahan masalah matematika. Dengan acuan kriteria ketuntasan minimal secara klasikal yaitu 75 .

Tabel 1. Klasifikasi Hasil Belajar Siswa

\begin{tabular}{cl}
\hline Interval Skor Rata-Rata & klasifikasi \\
\cline { 2 - 3 } $90<X \leq 100$ & Sangat baik \\
\hline $80<X \leq 90$ & Baik \\
\hline $65<X \leq 80$ & Cukup \\
\hline $55<X \leq 65$ & Kurang \\
\hline$X \leq 55$ & Sangat kurang \\
\hline
\end{tabular}

Sumber : Nashiroh (2014:82)

2. Analisis Respon Siswa.

Data tentang hasil respon selanjunya dianalisis menggunakan penghitungan skor rata-rata pada setiap aspek, kemudian akan dikategorikan sesuai pada Tabel 2 berikut.

Tabel 2. Klasifikasi Penilaian Respon Siswa

Sumber : Nasiroh (2014)

\begin{tabular}{cl}
\hline Interval Skor Rata-Rata & Klasifikasi \\
\hline$X>4.2$ & Sangat baik \\
\hline $3.4<X \leq 4.2$ & Baik \\
\hline $2.6<X \leq 3.4$ & Cukup \\
\hline $1.8<X \leq 2.6$ & Kurang \\
\hline$X \leq 1.8$ & Sangat kurang \\
\hline
\end{tabular}

3. Analisis Efektifitas Pembelajaran Matematika dengan Menggunakan Media Pemberian Tugas Google Form di Masa Pandemi Covid-19

Efektifitas pembelajaran matematika menggunakan media pemberian tugas google form di masa pandemi Covid-19 dapat dikatakan efektif jika klasifikasi hasil belajar berada pada kriteria minimal cukup. Selain itu, jika respon siswa berada pada kriteria baik. 


\section{HASIL DAN PEMBAHASAN}

\section{Hasil Penelitian}

1. Hasil Belajar Siswa

Data yang akan diuraikan dalam bagian ini yaitu hasil tes yang telah diperoleh dari seluruh siswa kelas VII. Hasil jawaban 252 siswa saat mengerjakan 30 soal. Tes dilakukan untuk mengetahui hasil belajar siswa terhadap ketuntasan belajar. Berikut disajikan hasil analisis hasil belajar yang sudah dilakukan.

Tabel 3. Hasil Belajar Siswa

\begin{tabular}{lcc}
\hline \multicolumn{1}{c}{ Uraian } & Jumlah & Persentase \\
\hline $\begin{array}{l}\text { Siswa yang } \\
\text { tuntas }\end{array}$ & 190 & $75.4 \%$ \\
\hline $\begin{array}{l}\text { Siswa yang } \\
\text { tidak tuntas }\end{array}$ & 62 & $24.6 \%$ \\
\hline Jumlah & 252 & $100 \%$ \\
\hline
\end{tabular}

Berdasarkan Tabel 2 di atas diperoleh informasi bahwa untuk siswa yang tuntas sebesar $75.4 \%$ siswa di atas nilai KKM yaitu 70 siswa sehingga berada pada klasifikasi cukup untuk hasil belajar siswa. Hal ini secara KKM klasikal sudah memenuhi yaitu $75 \%$.

Faktor yang menjadikan siswa bisa menyelesaikan masalah matematika salah satunya yaitu mereka mempunyai pengetahuan awal, siswa juga wajib dapat memanfaatkan pengetahuan yang telah dimiliki saat memecahkan permasalahan matematika saat sedang dihadapi. Dalam melakukan analisa pengetahuan yang telah siswa miliki, maka didalam hal ini dilakukan penelitian untuk melihat hasil tes siswa. Dalam pengambilan sampel soal seperti berikut:

Soal nomor 1 memiliki kompetensi memakai sifat-sifat operasi hitung bilangan bulat serta pecahan saat memecahkan masalah, untuk pengetahuan yang telah dimiliki siswa (resources) di dalam dirinya dapat dituangkan sebagai berikut. Tingkat pengetahuan (degree of knowledge) yaitu banyak siswa yang tidak mengetahui apaapa, selain itu juga terdapat siswa belum memahami masalah tetapi belum bisa mengerjakan dengan rinci tentang (1) Konsep: memakai sifat-sifat dari operasi bilangan bulat dan memakai bentuk aljabar dalam menyelesaikan masalah yang kaitannya dengan kehidupan sehari-hari. (2) Prosedur: melakukan operasi bentuk aljabar yang dipakai waktu penyelesaian masalah. 


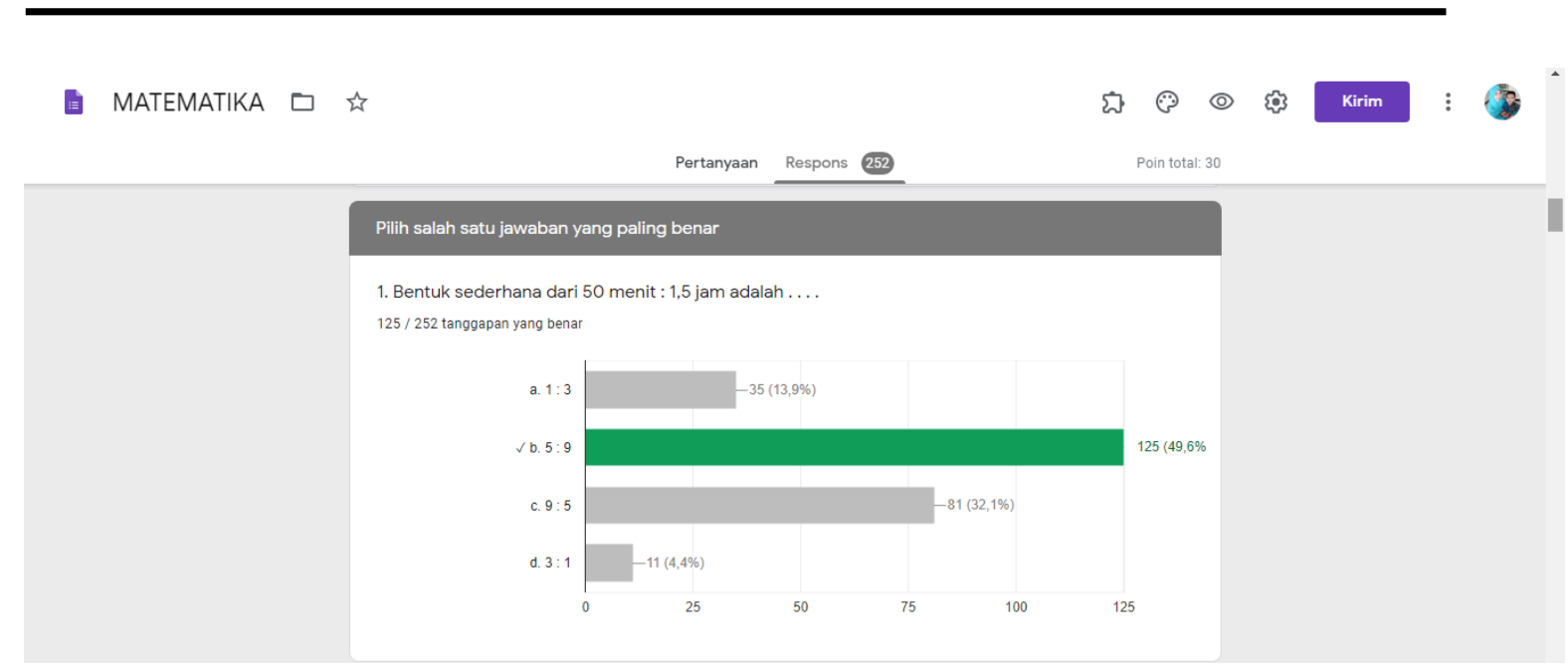

Gambar 1. Persentase Jawaban Siswa Soal 1

Dari Gambar 1 diperoleh informasi bahwa untuk jawaban benar pada soal nomer 1 yaitu pilihan b. Untuk siswa menjawab benar sebanyak 125 siswa atau sebesar $49.6 \%$ siswa yang menjawab benar untuk soal nomer 1.

Pada soal nomor 3 dengan kompetensi jarak, waktu, dan kecepatan, dari pengetahuan yang telah siswa miliki (resources) dalam dirinya dinyatakan seperti berikut:tingkat pengetahuan (degree of know-ledge) adalah terdapat beberapa siswa di strata tinggi yang mereka percaya diri terhadap pengetahuannya tentang fakta (fact) ataupun konsep tentang penulisan simbol pecahan serta bagaimana mendapatkan hasil terbesar di dalam pecahan (pembagian bilangan).

- MATEMATIKA $\square$ 宁

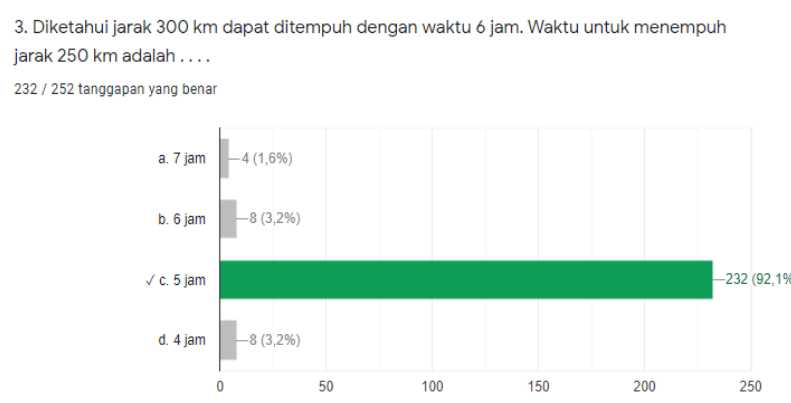

Gambar 2. Persentase Jawaban Siswa Soal 3 
Dari Gambar 2 diperoleh informasi bahwa untuk jawaban benar pada soal nomer 3 yaitu pilihan c. Untuk siswa menjawab benar sebanyak 232 siswa atau sebesar $92.1 \%$ siswa yang menjawab benar untuk soal nomer 3.

Pada soal nomor 8 dengan kompetensi menentukan perbandingan, pengetahuan yang telah siswa miliki (resources) didalam dirinya dinyatakan seperti berikut. Tingkat pengetahuan (degree of knowledge) adalah: seorang siswa bisa menduga dari jawaban dengan detail, tetapi kurang memperoleh kepastian tentang kebenaran jawaban mereka mengenai fakta (fact) maupun konsep tentang bagaimana cara menyelesaikan masalah saat menggunakan konsep perbandingan.

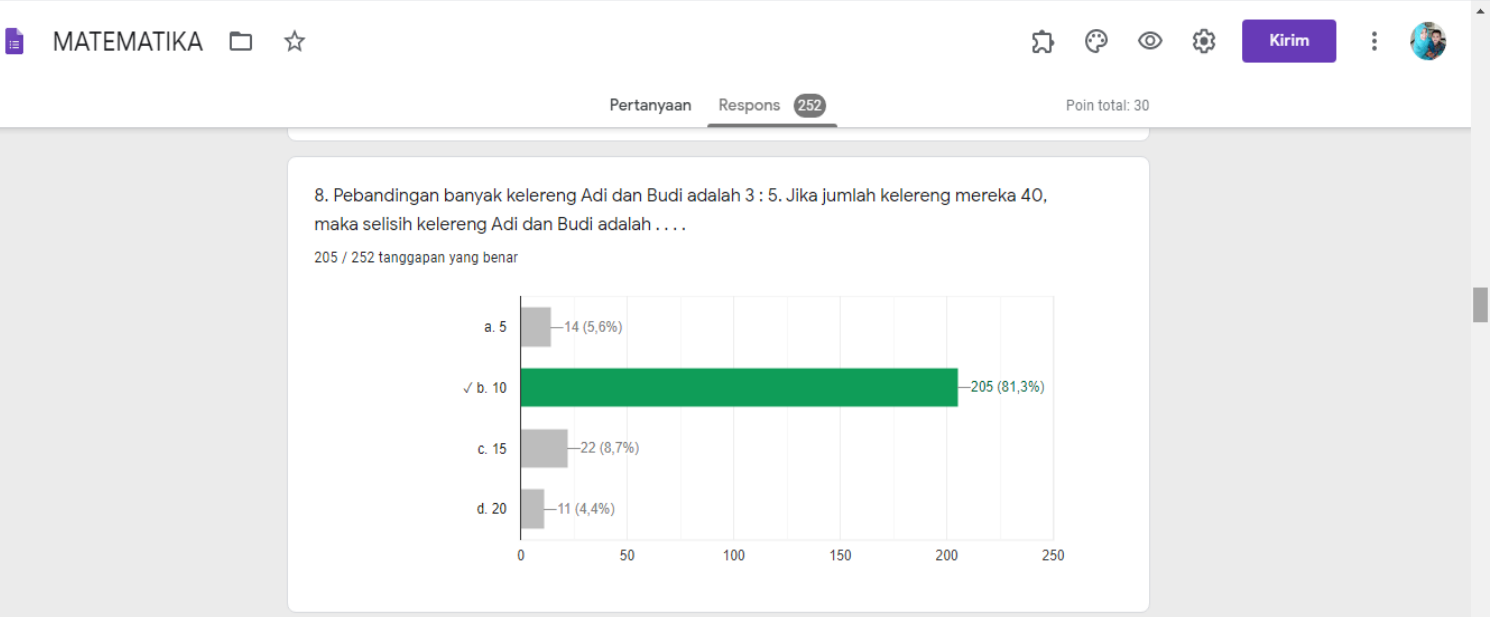

\section{Gambar 3. Persentase Jawaban Siswa Soal 8}

Dari Gambar 3 diperoleh informasi bahwa untuk jawaban benar pada soal nomer 8 yaitu pilihan b. Untuk siswa menjawab benar sebanyak 205 siswa atau sebesar $81.3 \%$ siswa yang menjawab benar untuk soal nomer 8 .

Soal nomor 9 dengan kompetensi yaitu memecahkan masalah yang berhubungan dengan perbandingan serta skala, pengetahuan telah dikuasai (resources) di dalam diri siswa yang dinyatakan seperti berikut. Tingkat pengetahuan (degree of knowledge): sebagian besar Siswa yang memiliki jawaban dengan benar tentang fakta (fact) ataupun konsep tentang cara dalam menyelesaikan masalah dengan memakai perbandingan dan skala. 
目 MATEMATIKA $\square$ 㕣

Pertanyaan Respons 252

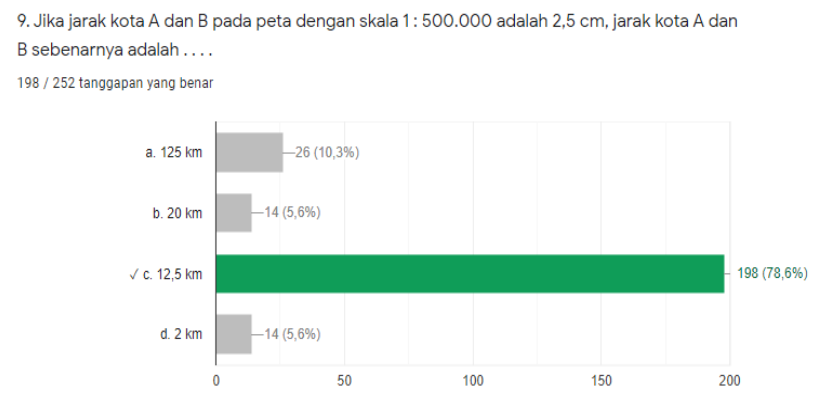

Gambar 4. Persentase Jawaban Siswa Soal 9

Dari Gambar 4 diperoleh informasi bahwa untuk jawaban benar pada soal nomer 9 yaitu pilihan c. Untuk siswa menjawab benar sebanyak 198 siswa atau sebesar $78.6 \%$ siswa yang menjawab benar untuk soal nomer 9.

Pada soal nomor 24 dengan kompetensi menentukan luas bangun datar, pengetahuan yang telah dikuasai (resources) didalam diri seorang siswa dinyatakan seperti berikut. Untuk tingkat pengetahuan (degree of knowledge): mayoritas siswa yang dapat mengetahui bagaimana menyelesaikan masalah yang berkaitan dengan bangun datar.

- MATEMATIKA $\square$

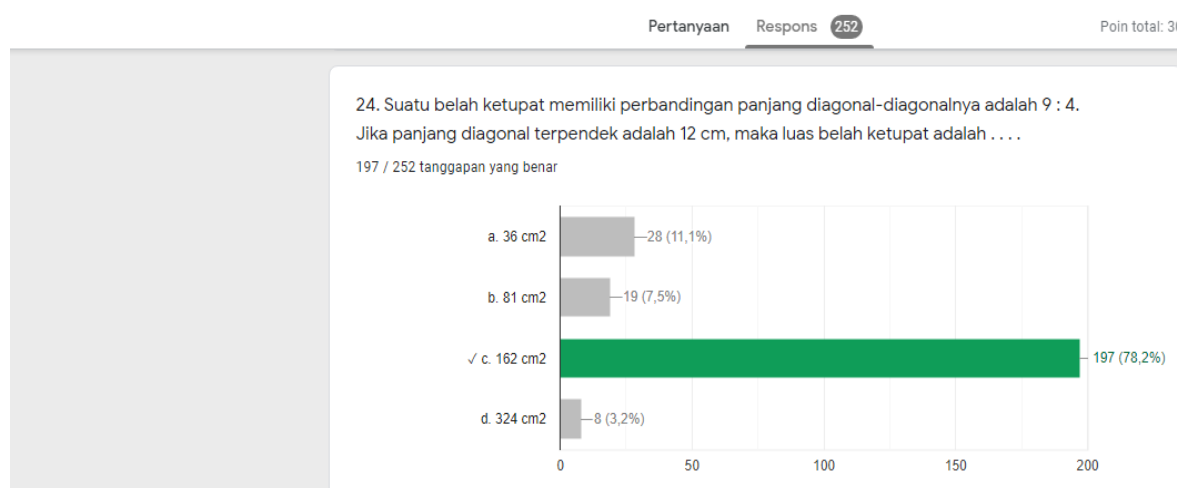

Gambar 5. Persentase Jawaban Siswa Soal 24

Dari Gambar 5 diperoleh informasi bahwa untuk jawaban benar pada soal nomer 24 yaitu pilihan c. Untuk siswa menjawab benar sebanyak 197 siswa atau sebesar $78.2 \%$ siswa yang menjawab benar untuk soal nomer 24 . 
2. Respon Siswa Terhadap Pembelajaran Matematika Menggunakan Media Pemberian Tugas Google Form di Masa Pandemi Covid-19

Salah satu faktor terpenting dalam kesuksesan penggunaan media pemberian tugas Google Form adalah siswa. Sebanyak 90 \% siswa telah mampu mengoperasikan komputer, selain itu siswa juga sudah memiliki akun email Google. Selain itu juga siswa telah mampu menggunakan internet untuk mengakses website serta melakukan komunikasi lewat email. Data respon siswa didapatkan dari hasil angket yang telah disebarkan pada siswa, sperti pada Tabel 4 dibawah:

Tabel 4. Hasil Respon Siswa

\begin{tabular}{lc}
\hline \multicolumn{1}{c}{ Aspek } & Skor Rata-rata \\
\hline $\begin{array}{l}\text { Pengoperasian/Penggunaan } \\
\text { Media }\end{array}$ & 4 \\
\hline $\begin{array}{l}\text { suka penggunaan Google } \\
\text { Form }\end{array}$ & 3.7 \\
\hline Mudah diakses & 4 \\
\hline Efisiensi waktu & 3.9 \\
\hline Menghemat kertas & 4 \\
\hline Rata - Rata Akhir & 3.9 \\
\hline Kategori & Baik \\
\hline
\end{tabular}

Berdasarkan hasil pada Tabel 4 di atas, diperoleh bahwa respon siswa pada saat pembelajaran matematika menggunakan media pemberian tugas Google Form sebesar 3.9, dengan kategori baik.

3. Efektifitas Pembelajaran Matematika Menggunakan Media Pemberian Tugas Google Form di Masa Pandemi Covid-19

Dari hasil analisis data pada point 1 dan 2 diperoleh data bahwa hasil belajar siswa berada pada klasifikasi cukup. Sedangkan untuk respon siswa berada pada klasifikasi baik. Sehingga dengan demikian bisa dibuat kesimpulan bahwa pembelajaran matematika memanfaatkan media pemberian tugas Google Form di masa pandemi Covid-19 dikatakan efektif.

\section{Pembahasan}

Di dalam penelitian ini, untuk efektifitas pembelajaran matematika menggunakan media pemberian tugas Google Form diperoleh dari ketuntasan hasil 
belajar dan respon siswa. Hal ini senada dengan pendapat Sabarata (Lutfiyah \& Sulisawati, 2019), yang mengatakan jika ketuntasan hasil belajar merupakan salah satu syarat penting yang harus diperhatikan saat menunjukkan efektivitas pembelajaran. Dalam Hasil penelitian memperlihatkan bahwa hasil ketuntasan hasil belajar yang diperoleh siswa sebesar $75.4 \%$ siswa diatas nilai KKM yaitu 70 sehingga berada pada klasifikasi cukup. Untuk KKM klasikal minimal sudah memperoleh 75\%.

Hasil penelitian ini juga dipereoleh bahwa respon siswa terhadap pembelajaran matematika memanfaatkan media pemberian tugas Google Form di masa pandemi Covid-19 berada pada klasifikasi baik. Siswa suka menggunakan Google Form, mudah diakses, waktu efisien, serta menghemat kertas. Hal ini dikarenakan Google form mudah dioperasikan dan mudah diakses. Pendapat tersebut didukung oleh Santoso (2019) yang meyebutkan bahwa Google Form memiliki beberapa kelebihan diantaranya (1) mudah digunakan, (2) bisa dinikmati dengan gratis, (3) programnya ringan, (4) dapat dibagikan ke berbagai platform, (5) mempunyai fitur SpreadSheets sehingga bisa melihat tanggapan survei yang telah dikumpulkan pada formulir secara rapi serta otomatis.

\section{KESIMPULAN DAN SARAN}

Berdasarkan dari hasil analisis data serta pembahasan yang telah dilaksanakan yaitu pembelajaran matematika menggunakan media pemberian tugas google form dimasa pandemi covid-19, maka bisa didapatkan kesimpulan bahwa 1) hasil belajar siswa yang tuntas mencapai $75.4 \%$ dan berada pada klasifikasi baik, 2) respon siswa terhadapa pemberian tugas Google Form berada pada kategori baik. Sehinga dari kedua kategori tersebut bisa dibuat kesimpulan bahwa pembelajaran matematika menggunakan media pemberian tugas Google Form dimasa pandemi Covid-19 dikatakan efektif.

\section{REFERENSI}

Dimyati dan Mudjiono. (2015). Belajar dan Pembelajaran. Jakarta:Rineka Cipta.

Lutfiyah \& Sulisawati, D.N. 2019. Efektivitas Pembelajaran Matematika Menggunakan Media Berbasis E-Learning. Jurnal Pendidikan Matematika: Judika Education. Vol 2 No 1 Januari-Juni 2019 hal 58-65. Disajikan di 
https://journal.ipm2kpe.or.id/index.php/JUDIKA/article/view/716/429.

Diakses 20 September 2020.

Nasiroh, D. (2014). Pengembangan Model dengan Pendekatan Kontekstual pada Materi Barisan dan Deret untuk Peserta didik SMP Terbuka Kelas IX. Skripsi. Yogyakarta: FMIPA.

Putra, E.D., \& Amalia, R. 2019. Deskripsi Kemampuan Komunikasi Matematis Siswa Dalam Pembelajaran Matematika Nalaria Realistik. Jurnal Dimensi Pendidikan dan Pembelajaran, Vol 7, No 2, Juli 2019 hal 61-73. Disajikan di http://journal.umpo.ac.id/index.php/dimensi/article/view/1801/1122.

Diakses 10 September 2020.

Santoso, P.B. 2019. Efektivitas Penggunaan Media Penilaian Google Form Terhadap Hasil Belajar Pelajaran TIK. Prosiding Seminar Nasional: Kebijakan dan Pengembangan Pendidikan di Era Revolusi Industri 4.0. disajikan di https://jurnal.ustjogja.ac.id/index.php/snpep2019/article/view/5711/2767. Diakses 09 November 2020.

Sianipar, A.Z. 2019. Penggunaan Google Form Sebagai Alat Penilaian Kepuasan Pelayanan Mahasiswa. Journal of Information System, Apllied, Management, Acoounting and Research Vol 3 No 1 Februari 2019 hal 16-22. Disajikan di http://journal.stmikjayakarta.ac.id/index.php/jisamar/article/view/72/67 diakses 20 oktober 2020.

Surya, M. (2004). Psikologi pembelajaran \& pengajaran. Bandung, Indonesia: Pustaka BaniQuraisy.

Trianto, 2011. Model Pembelajaran Terpadu: Konsep, Strategi, dan Implementasinya dalam Kurikulum Tingkat Satuan Pendidikan. Jakarta: Bumi Aksa 